\title{
Glutamine Metabolism in Children with Short-Bowel Syndrome: A Stable Isotope Study
}

\author{
R. HANKARD, O. GOULET, C. RICOUR, M. RONGIER, V. COLOMB, \\ AND D. DARMAUN \\ Service de Gastroentérologie et Nutrition, Hôpital Necker-Enfants-Malades, Paris /R.H., O.G., \\ C.R., V.C.I, and INSERM U 290, Hôpital Saint-Lazare, Paris, France (R.H., M.R., D.D./
}

\section{ABSTRACT}

Because glutamine is thought to be a major fuel for developing gut, we tested the hypothesis that extensive small-bowel resection alters whole-body glutamine metabolism in vivo. Eleven infants and children who had undergone extensive small intestinal resection (residual bowel length: $35 \pm 13 \mathrm{~cm}$; mean $\pm \mathrm{SD}$ ) and four control infants received $4-\mathrm{h}$ primed, continuous i.v. infusions of $\mathrm{L}-[1$ $\left.{ }^{13} \mathrm{C}\right]$ leucine and $\mathrm{L}-\left[2-{ }^{15} \mathrm{~N}\right]$ glutamine in the postabsorptive state. The appearance rates of glutamine and leucine into plasma were determined from stable isotope enrichments in plasma at steady state. We observed the following: 1 ) Regardless of intestinal status, leucine and glutamine fluxes were higher in infants than values previously reported for adults. 2) Small-bowel resection was associated with a

The prominent role of the small intestine in glutamine utilization has been established in a variety of animal species (1-3). In the rat, glutamine uptake by the small intestine accounts for $20 \%$ of overall glutamine utilization; glutamine oxidation supplies a third of the total energy requirement of this tissue (3). In humans, glutamine concentration was found to be $13-17 \%$ higher in arterial blood than in portal blood in adults undergoing elective cholecystectomy (4) or in multitrauma patients submitted to exploratory laparotomy (5). Recently, we have developed stable isotope methods to quantitate rates of glutamine production and utilization in vivo $(6$, 7), and we observed that the rate of whole-body glutamine utilization was decreased about $20 \%$ in adult patients after extensive resection of the small intestine. This was observed despite the fact that patients were studied several months after surgery and were in a near normal nutritional status long after they had been weaned from PN (8). These findings suggested that intestinal resection per se caused a reduction in overall glutamine utilization. Studies performed in animals have shown that glutamine

Received September 24, 1993; accepted March 4, 1994

Correspondence: Dominique Darmaun, M.D., Ph.D., Nemours Children's Clinic, PO Box 5720, Jacksonville, FL. 32247. reduction in glutamine appearance rate $(568 \pm 124$ $\mu \mathrm{mol} \cdot \mathrm{kg}$ lean body mass ${ }^{-1} \cdot \mathrm{h}^{-1}$ in short-bowel syndrome infants versus $816 \pm 149 \mu \mathrm{mol} \cdot \mathrm{kg}$ lean body mass ${ }^{-1} \cdot \mathrm{h}^{-1}$ in control infants; $p<0.05$ ). 3) In contrast, leucine appearance rate was unaltered in short-bowel syndrome patients. The findings suggest that the small intestine plays a prominent role in glutamine metabolism in human infants. (Pediatr Res 36: 202-206, 1994)
$\mathbf{R a}$, appearance rate
$\mathbf{R a}_{\text {GLN }}$, glutamine flux
$\mathbf{P N}$, parenteral nutrition

Abbreviations

is used by the developing (9) as well as the adult small intestine (3). To our knowledge, however, neither glutamine kinetics nor the contribution of the small intestine to glutamine metabolism has been assessed in human infants. If glutamine is indeed a major fuel for the human infant small intestine, extensive bowel resection may alter whole-body glutamine kinetics in that population. We therefore used tracer techniques to quantitate glutamine kinetics in a group of children with short-bowel syndrome.

\section{METHODS}

Patients. Informed consent was obtained from the parents of all the infants studied according to protocols approved by the Ethics Committee of Necker EnfantsMalades Hospital. A total of 15 children were studied: four controls and 11 children who had undergone extensive small intestinal resection. Inclusion criteria were 1 ) a fair and stable nutritional status; 2) the absence of surgical procedure in the 6 mo before study; 3 ) the absence of sepsis or neoplasia; 4) a residual small-bowel length of less than $50 \mathrm{~cm}$; and 5) a normal growth velocity for age over the few months before study. Extensive enterectomy had been performed during the neonatal period 
because of intestinal atresia $(n=5)$, volvulus $(n=2)$, extensive intestinal angioma $(n=2)$, necrotizing enterocolitis $(n=1)$, and teratoma $(n=1)$. Small-bowel length was measured at the time of surgery along the antimesenteric side. Control patients had an intact small bowel. They were hospitalized for evaluation of failure to thrive $(n=2)$, rectal Hirschsprung's disease $(n=1)$, or Alagille's syndrome (a syndrome associating cholestasis, cardiac anomalies, butterfly vertebrae, embryotoxon, and abnormal facial features; $n=1$ ). None of the controls had any evidence of sepsis, neoplasia, or any disease of the gastrointestinal tract, and none had undergone surgery in the recent past. Patients and controls had the same energy intake, with $10 \%$ of total energy (parenteral, oral, or both) provided as protein. Skinfold thickness was measured at four sites by the same observer, using a Holtain-Harpenden skinfold caliper (Holtain Ltd., Grymmych, Wales, UK). Body density was calculated based on skinfold measurements (10), and the percentage of body weight accounted for by fat mass was derived from body density (11). Lean body mass was calculated as the difference between body weight and fat mass.

Protocol design. All infants were studied in the postabsorptive state. The night before the study, patients were admitted to the nutrition unit and received their regular oral or PN intake until $0600 \mathrm{~h}$ the next morning. Studies were begun at $1000 \mathrm{~h}$, i.e. $4 \mathrm{~h}$ after discontinuation of oral or parenteral feeding. Patients who already had a central catheter received the isotopes through the central line. When children had no central catheter, an indwelling "butterfly" needle was inserted into a superficial vein of the arm to infuse the isotopes. Another indwelling needle was placed on the opposite limb for blood sampling. At $1000 \mathrm{~h}$, a baseline 1-mL blood sample was drawn to determine background isotopic enrichment in plasma amino acids, and a primed, continuous infusion of sterile, pyrogen-free solutions providing $3 \mu \mathrm{mol} \cdot \mathrm{kg}^{-1} \cdot \mathrm{h}^{-1} \mathrm{~L}-[1-$ $\left.{ }^{13} \mathrm{C}\right]$ leucine and $10 \mu \mathrm{mol} \cdot \mathrm{kg}^{-1} \cdot \mathrm{h}^{-1} \mathrm{~L}-\left[2-{ }^{15} \mathrm{~N}\right]$ glutamine $\left(90 \%{ }^{13} \mathrm{C}\right.$ and $97 \%{ }^{15} \mathrm{~N}$, respectively; both from CEA, Gif-sur-Yvette, France) was administered i.v. for $4 \mathrm{~h}$ using a calibrated syringe pump (Vial Medical, VélizyVillacoublay, France) $(6,8)$. During the last $2 \mathrm{~h}$ of infusion, the forearm was heated $\left(\approx 60^{\circ} \mathrm{C}\right)$ with a heating pad to obtain four $1-\mathrm{mL}$ arterialized venous blood samples (12) at 30-min intervals.

Analytical procedures. Isotopic enrichments were determined in plasma amino acids by gas chromatographymass spectrometry using a Nermag R 1010 T instrument (Nermag, Argenteuil, France) with a precision of approximately $1 \%$. Glutamine was isolated for derivatization by passing the deproteinized, neutralized plasma over disposable anion-exchange columns as previously described (7). Plasma glutamine was analyzed as its $\mathrm{N}$-acetyl, n-propyl ester derivative (7) and leucine as its N-trifluoroacetyl, n-butyl derivative $(8,13)$. Plasma glutamine concentrations $(\mu \mathrm{M})$ were determined by reverse isotope dilution of a ${ }^{2} \mathrm{H}_{3}$-glutamine (Tracer Technologies, Som- erville, MA) internal standard that was added to the samples at the time of sampling (7).

Calculations. Amino acid $\mathrm{Ra}$ were calculated using standard equations for steady state: $\mathrm{Ra}=\mathrm{i}(\mathrm{Ei} / \mathrm{Ep}-1)$, where $\mathrm{i}$ is the tracer infusion rate $\left(\mu \mathrm{mol} \cdot \mathrm{kg}^{-1} \cdot \mathrm{h}^{-1}\right)$, and $\mathrm{Ei}$ and $\mathrm{Ep}$ (mole \% excess) are the tracer enrichments in the infusate and plasma, respectively, at steady state. Isotopic steady state was defined by a coefficient of variation $<10 \%$ over the last $2 \mathrm{~h}$ of infusion. Under conditions of steady state, the $\mathrm{Ra}$ of an amino acid is equal to its rate of disappearance, and $\mathrm{Ra}$ therefore measures both the production and utilization of the amino acid.

Because leucine is an essential amino acid, its $\mathrm{Ra}$ $\left(\mathrm{Ra}_{\mathrm{LEU}}\right)$ is entirely derived from protein breakdown in the postabsorptive state. In contrast, glutamine, a dietary nonessential amino acid, has two inflow components to its flux, release from protein breakdown $\left(\mathrm{B}_{\mathrm{GLN}}\right)$ and de novo synthesis $\left(\mathrm{D}_{\mathrm{GLN}}\right): \mathrm{Ra}_{\mathrm{GLN}}=\mathrm{B}_{\mathrm{GLN}}+\mathrm{D}_{\mathrm{GLN}} \cdot \mathrm{B}_{\mathrm{GLN}}$ is estimated based on the assumption that the release of an amino acid from protein breakdown depends solely on the rate of protein breakdown and the abundance of this amino acid in body protein, e.g. $13.5 \mathrm{~g}(92.5 \mathrm{mmol})$ of glutamine and $8 \mathrm{~g}(61.0 \mathrm{mmol})$ of leucine per $100 \mathrm{~g}$ of protein: $\mathrm{B}_{\mathrm{GLN}}=\mathrm{Ra}_{\mathrm{LEU}} \times 92.5 / 61.0$. Therefore, $\mathrm{D}_{\mathrm{GLN}}=$ $\mathrm{Ra}_{\mathrm{GLN}}-\mathrm{B}_{\mathrm{GLN}}$, where $\mathrm{Ra}_{\mathrm{GLN}}, \mathrm{B}_{\mathrm{GLN}}$, and $\mathrm{D}_{\mathrm{GLN}}$ are expressed in $\mu \mathrm{mol} \cdot \mathrm{kg}^{-1} \cdot \mathrm{h}^{-1}$. Glutamine metabolic clearance rate $\left(\mathrm{L} \cdot \mathrm{kg}^{-1} \cdot \mathrm{h}^{-1}\right)$ was calculated as follows: $\mathrm{Ra}_{\mathrm{GLN}} /[\mathrm{Gln}]$, where [GIn] is plasma glutamine concentration $(\mu \mathrm{M})$ at steady state.

Comparisons between groups were performed using nonparametric Mann-Whitney test.

\section{RESULTS}

Relevant clinical and nutritional characteristics of the infants are summarized in Table 1 . Six of the infants who had undergone small-bowel resection received supplementation with PN (patients 1-6) in addition to oral feeding. In this group, oral feeding represented 30 to $70 \%$ of total energy intake. Five infants with small-bowel resection (patients 7-11) had been weaned from PN $21 \pm$ 12 mo before the study.

Isotopic enrichment reached steady state in plasma glutamine and leucine over the last $2 \mathrm{~h}$ of tracer infusion (Table 2). Whether expressed per $\mathrm{kg}$ of body weight or per $\mathrm{kg}$ of lean body mass, $\mathrm{Ra}_{\mathrm{GLN}}$ was significantly decreased in short-bowel syndrome patients. The reduction in glutamine flux seems to be caused by a lower rate of $d e$ novo synthesis, yet the difference failed to reach statistical significance. There was no difference between the two groups with regard to plasma glutamine concentrations or rates of protein turnover (whether expressed as glutamine release from protein breakdown or leucine flux). Within the small population studied, there was no correlation between $\mathrm{Ra}_{\mathrm{GLN}}$ and age or between $\mathrm{Ra}_{\mathrm{GLN}}$ and residual small-bowel length. 
HANKARD ET $A L$.

Table 1. Clinical and nutritional characteristics of patients*

\begin{tabular}{|c|c|c|c|c|c|c|c|c|c|}
\hline & \multirow{2}{*}{$\begin{array}{l}\text { Age } \\
(\mathrm{mo})\end{array}$} & \multicolumn{2}{|c|}{ Weight } & \multirow{2}{*}{$\begin{array}{l}\text { Growth rate } \\
\left(\mathrm{cm} \cdot \mathrm{mo}^{-1}\right)\end{array}$} & \multirow{2}{*}{$\begin{array}{l}\text { Fat mass } \\
(\% \mathrm{BW})\end{array}$} & \multirow{2}{*}{$\begin{array}{l}\text { SBL } \\
(\mathrm{cm}) \\
\end{array}$} & \multirow{2}{*}{$\begin{array}{c}\text { Alb } \\
(\mathrm{g} / \mathrm{dL})\end{array}$} & \multicolumn{2}{|c|}{ Energy intake } \\
\hline & & $\mathrm{kg}$ & $\%$ IBW & & & & & $\mathrm{kcal} \cdot \mathrm{kg}^{-1} \cdot \mathrm{d}^{-1}$ & $\% \mathrm{PO}$ \\
\hline \multicolumn{10}{|l|}{ Patient } \\
\hline 1 & 9 & 8.0 & 100 & 1.5 & 17.5 & 51 & 4.0 & 100 & 38 \\
\hline 2 & 11 & 10.2 & 120 & 0.6 & 12.7 & 17 & 3.9 & 94 & 41 \\
\hline 3 & 21 & 8.5 & 107 & 1.2 & 16.7 & 25 & 4.0 & 81 & 72 \\
\hline 4 & 34 & 15.3 & 106 & 1.0 & 15.0 & 30 & 4.2 & 118 & 33 \\
\hline 5 & 24 & 10.0 & 90 & 1.2 & 8.4 & 60 & 4.0 & 130 & 70 \\
\hline 6 & 24 & 11.7 & 106 & ND & 13.7 & 40 & 4.0 & 111 & 54 \\
\hline 7 & 29 & 13.3 & 106 & 0.8 & 18.0 & 40 & 4.3 & 98 & 100 \\
\hline 8 & 55 & 17.0 & 100 & 0.8 & 13.5 & 40 & 3.9 & 88 & 100 \\
\hline 9 & 45 & 16.8 & 105 & 0.7 & 17.3 & 25 & 4.0 & 75 & 100 \\
\hline 10 & 80 & 16.4 & 103 & 0.6 & 8.5 & 26 & 4.0 & 122 & 100 \\
\hline 11 & 12 & 10.8 & 92 & 1.7 & 16.7 & 26 & 3.8 & 111 & 100 \\
\hline $\begin{array}{l}\text { Mean } \pm S D \\
\text { Control }\end{array}$ & $31 \pm 21$ & $13 \pm 3$ & $103 \pm 8$ & $1.0 \pm 0.4$ & $15.0 \pm 2.8$ & $35 \pm 13$ & $4.0 \pm 0.1$ & $102 \pm 17$ & $73 \pm 28$ \\
\hline 12 & 8 & 7.0 & 90 & 1.0 & 14.3 & Whole & 4.5 & 143 & 100 \\
\hline 13 & 11 & 6.7 & 110 & 1.0 & 13.4 & Whole & 3.8 & 134 & 100 \\
\hline 14 & 20 & 12.9 & 110 & 0.9 & 14.0 & Whole & 3.7 & 92 & 100 \\
\hline 15 & 12 & 8.0 & 115 & 0.9 & 9.4 & Whole & 4.2 & 109 & 100 \\
\hline Mean \pm SD & $13 \pm 4$ & $8.6 \pm 2.9$ & $106 \pm 11$ & $1.0 \pm 0.1$ & $12.8 \pm 2.0$ & & $4.1 \pm 0.3$ & $119 \pm 20$ & $100 \pm 0$ \\
\hline
\end{tabular}

* \% IBW, percent of ideal body weight; BW, body weight; SBL, residual small-bowel length; Alb, serum albumin level; \% PO, oral intake as a fraction of total calorie intake; ND, not determined. All data are means \pm SD.

\section{DISCUSSION}

Based on i.v. infusion of stable isotope-labeled amino acids, the current study provides evidence for a lower rate of whole-body glutamine production and utilization in infants who have undergone extensive resection of the small intestine. Although glutamine metabolism was assessed at the level of the whole body rather than directly measured in the intestinal bed, the present findings suggest that the lower glutamine flux may be attributed to enterectomy per se. Indeed, whole-body protein turnover (as reflected by leucine flux) was not altered by enterectomy; therefore, alterations in overall protein homeostasis could not explain our finding on glutamine.

The reduction of $\mathrm{Ra}_{\mathrm{GLN}}$ in short-gut infants is unlikely to result from differences in nutritional status, dietary intake, or body composition because 1) the patients' nutritional status was fair; 2) their energy intake was similar to that of controls (Table 1); and 3) their glutamine $\mathrm{Ra}$ was still decreased when expressed per $\mathrm{kg}$ of lean body mass - an estimate of the body's metabolically active mass (14). The route of nutrient delivery did not seem to have any major impact on glutamine $\mathrm{Ra}$, inas-

Table 2. Glutamine and leucine metabolism in enterectomized infants*

\begin{tabular}{|c|c|c|c|c|c|c|c|c|c|c|}
\hline & $\begin{array}{l}\text { Ep }_{\text {LEU }} \\
\text { (mole \% }\end{array}$ & $\begin{array}{l}E p_{G L N} \\
\text { excess) }\end{array}$ & $\begin{array}{l}\mathrm{Ra}_{\text {LEU }} \\
(\mu \mathrm{mol} \cdot \mathrm{kg}\end{array}$ & $\begin{array}{r}\mathrm{Ra}_{\mathrm{GLN}} \\
\left.\mathrm{g}^{-1} \cdot \mathrm{h}^{-1}\right) \\
\end{array}$ & $\mathrm{Ra}_{\text {LEU }}$ & $\begin{array}{c}\mathrm{Ra}_{\mathrm{GLN}} \\
(\mu \mathrm{mol} \cdot \mathrm{kg} \mathrm{LBI} \\
\end{array}$ & $\begin{array}{c}\mathbf{B}_{\mathrm{GLN}} \\
\left.3 \mathrm{M}^{-1} \cdot \mathbf{h}^{-1}\right) \\
\end{array}$ & $D_{\text {GILN }}$ & $\begin{array}{l}{[\mathrm{G} \ln ]} \\
(\mu \mathrm{M})\end{array}$ & $\begin{array}{c}\mathrm{MCR}_{\mathrm{GLN}} \\
\left(\mathrm{L} \cdot \mathrm{kg} \mathrm{LBM}^{-1} \cdot \mathrm{h}^{-1}\right) \\
\end{array}$ \\
\hline \multicolumn{11}{|l|}{ Patients } \\
\hline 1 & ND & $1.69 \pm 0.10$ & ND & 439 & ND & 532 & ND & ND & 320 & 1.66 \\
\hline 2 & $1.94 \pm 0.07$ & $1.19 \pm 0.10$ & 155 & 568 & 177 & 651 & 308 & 343 & 490 & 1.33 \\
\hline 3 & $1.81 \pm 0.09$ & $2.12 \pm 0.10$ & 165 & 411 & 198 & 493 & .344 & 149 & 562 & 0.88 \\
\hline 4 & $1.84 \pm 0.13$ & $1.90 \pm 0.10$ & 162 & 577 & 191 & 679 & 332 & 347 & 531 & 1.28 \\
\hline 5 & $1.50 \pm 0.10$ & $1.99 \pm 0.11$ & 260 & 584 & 314 & 695 & 546 & 149 & 573 & 1.21 \\
\hline 6 & $2.28 \pm 0.05$ & $2.99 \pm 0.05$ & 138 & 392 & 160 & 454 & 278 & 176 & 416 & 1.09 \\
\hline 7 & $2.19 \pm 0.19$ & $3.48 \pm 0.09$ & 173 & 334 & 211 & 407 & 367 & 40 & 283 & 1.44 \\
\hline 8 & $2.25 \pm 0.14$ & $2.27 \pm 0.17$ & 159 & 448 & 184 & 518 & 320 & 198 & 496 & 1.04 \\
\hline 9 & $1.31 \pm 0.142$ & $2.05 \pm 0.13$ & 231 & 506 & 275 & 611 & 478 & 133 & 813 & 0.75 \\
\hline 10 & $1.15 \pm 0.10$ & $1.36 \pm 0.14$ & 318 & 734 & 348 & 802 & 605 & 197 & 577 & 1.39 \\
\hline 11 & $2.29 \pm 0.10 ?$ & $3.07 \pm 0.24$ & 183 & 334 & 219 & 401 & 381 & 20 & 542 & 0.74 \\
\hline Mean $\pm S D$ & & & $194 \pm 574$ & $484 \pm 123 \dagger$ & $228 \pm 60$ & $568 \pm 124 \dagger 3$ & $396 \pm 104$ & $175 \pm 100$ & $509 \pm 135$ & $1.16 \pm 0.30$ \\
\hline \multicolumn{11}{|c|}{$500 \pm 1241590 \pm 104 \quad 1 / 2 \pm 104509 \pm 135$} \\
\hline 12 & $1.66 \pm 0.21$ & $1.75 \pm 0.05$ & 254 & 647 & 324 & 755 & 563 & 192 & 470 & 1.61 \\
\hline 13 & $2.18 \pm 0.13$ & $1.34 \pm 0.09$ & 155 & 630 & 190 & 728 & 330 & 398 & 414 & 1.76 \\
\hline 14 & $3.63 \pm 0.32$ & $1.57 \pm 0.10$ & 219 & 610 & 290 & 710 & 504 & 206 & 531 & 1.34 \\
\hline 15 & $1.70 \pm 0.06$ & $1.40 \pm 0.12$ & 226 & 972 & 249 & 1072 & 433 & 639 & 729 & 1.47 \\
\hline Mean $\pm S D$ & & & $213 \pm 427$ & $715 \pm 172 \dagger$ & $263 \pm 50$ & $816 \pm 149 \dagger$ & $457 \pm 87$ & $359 \pm 181$ & $536 \pm 119$ & $1.54 \pm 0.16$ \\
\hline
\end{tabular}

* ND, not determined; $\mathrm{Ep}_{\mathrm{LFU}}$, $\mathrm{Ep}_{\mathrm{GLN}}$ : steady state isotopic enrichment in plasma leucine and glutamine, respectively (mean $\left.\pm \mathrm{SD}\right) ; \mathrm{Ra}_{\mathrm{LEU}}$, leucine flux; $\mathrm{B}_{\mathrm{GL} . \mathrm{N}}$, glutamine release from protein breakdown; $\mathrm{D}_{\mathrm{GL} . \mathrm{N}}$, glutamine de novo synthesis; [GIn], plasma glutamine concentration; $\mathrm{MCR}_{\mathrm{GLN}}$, glutamine metabolic clearance rate; LBM, lean body mass.

$\dagger p<0.05$ between patients and controls (Mann-Whitney test). 
much as there was no detectable difference between those who had been weaned from PN and those who were still receiving supplements. Furthermore, all the infants were free of other disease processes that may affect glutamine metabolism such as cancer, sepsis, recent surgery, or disease of the immune system. Finally, we did not observe any correlation between age and $\mathrm{Ra}_{\mathrm{GLN}}$ in the infants studied; it is therefore unlikely that slight differences in patients' ages between groups could account for the findings.

Because our patients were studied more than 6 mo after surgery, some compensatory small-bowel growth or adaptation $(15,16)$ had most likely already taken place at the time of study; we do not have any estimate of the extent of this compensatory growth. However, if we assume the small-bowel length to be $\approx 270 \mathrm{~cm}$ in a normal neonate (17), our patients only retained $\approx 6-22 \%$ of their small bowel after surgery. After such an extensive resection, it is unlikely that small-bowel length had returned to $100 \%$ by the time of study; it is therefore safe to assume that our patients still had a decreased small intestinal mass compared with controls. Indeed, although the patients who had been completely weaned off PN at the time of study (patients 7-11; Table 2) presumably had experienced the greater compensatory intestinal growth, their glutamine Ra did not differ from that of patients who were still dependent on PN (patients 1-6).

Windmueller and Spaeth were first to quantitate the uptake of glutamine by the rat small intestine (3). In the human, Felig et al. (4) were first to document a positive arterioportal glutamine concentration gradient in vivo in adults undergoing elective cholecystectomy. Our present results are consistent with a previous study from our laboratory that used the same model and methodology to assess glutamine metabolism in the adult (8). The use of the short-bowel syndrome as an investigative model thus suggests that the small intestine is a target organ for glutamine utilization in both adults and infants in the human species.

Because glutamine turnover was measured at steady state, its reduction reflects a decline in both glutamine utilization and glutamine production. From our data, it cannot be ascertained which of these two processes occurred first. The reduction in glutamine $\mathrm{Ra}$ associated with enterectomy seems to be accounted for by a lower rate of de novo glutamine synthesis (Table 2). The difference in de novo synthetic rates failed to reach statistical significance in the current study; it did, however, reach significance in adult short-bowel syndrome patients (8). Nevertheless, it has to be kept in mind that, although $\mathrm{Ra}_{\mathrm{GLN}}$ is directly measured, glutamine de novo synthesis is a calculated value rather than a direct measurement and is therefore prone to large errors. Using arteriovenous gradient determination, other workers (18) have previously reported a marked decrease in the extremity glutamine efflux in septic adults who have undergone extensive small-bowel resection compared with patients exposed to a similar level of stress but with an intact bowel. In the postabsorptive state, the release of glutamine by "peripheral" skeletal muscle exceeds that of any other amino acid but alanine (19). A recent study confirms that skeletal muscle is the main source of glutamine; it accounts for $\approx 67 \%$ of glutamine $\mathrm{Ra}$ in healthy postabsorptive humans (20). Taken together, these studies suggest that although glutamine production takes place predominantly in peripheral (extrasplanchnic) tissues it may be controlled by the glutamine-requiring, i.e. splanchnic, tissues, among which the small bowel may play a prominent role.

Such an interorgan adaptive process should be triggered by a signal. The nature of this signal cannot be ascertained from the present data. Theoretically, the plasma glutamine concentration itself could be such a signal, inasmuch as glutamine is known to exert feedback inhibition on glutamine synthetase in cultured cells in vitro (21). Plasma glutamine concentrations did not differ between groups in the present study. However, the infants were studied long after enterectomy, and we could have missed transient alterations in glutamine concentration.

It is of interest to compare the amino acid kinetics obtained in the present study with those in adults $(6,8)$. Glutamine $\mathrm{Ra}$ was higher in control infants than in healthy adults $\left(715\right.$ versus $\left.344 \mu \mathrm{mol} \cdot \mathrm{kg}^{-1} \cdot \mathrm{h}^{-1}\right)$; the same holds true for short-bowel syndrome infants compared with short-bowel syndrome adults (484 versus 273 $\mu \mathrm{mol} \cdot \mathrm{kg}^{-1} \cdot \mathrm{h}^{-1}$; Figs. 1 and 2). Similarly, leucine $\mathrm{Ra}$ was higher in infants than in adults (194 versus 88 $\mu \mathrm{mol} \cdot \mathrm{kg}^{-1} \cdot \mathrm{h}^{-1}$ in short-bowel syndrome patients; 214 versus $89 \mu \mathrm{mol} \cdot \mathrm{kg}^{-1} \cdot \mathrm{h}^{-1}$ in controls). These higher amino acid fluxes are consistent with previous data reported for whole-body leucine fluxes in human newborns $(22,23)$. The higher leucine fluxes may be attributed to the higher protein turnover associated with the growth process (23). As for glutamine, several factors could

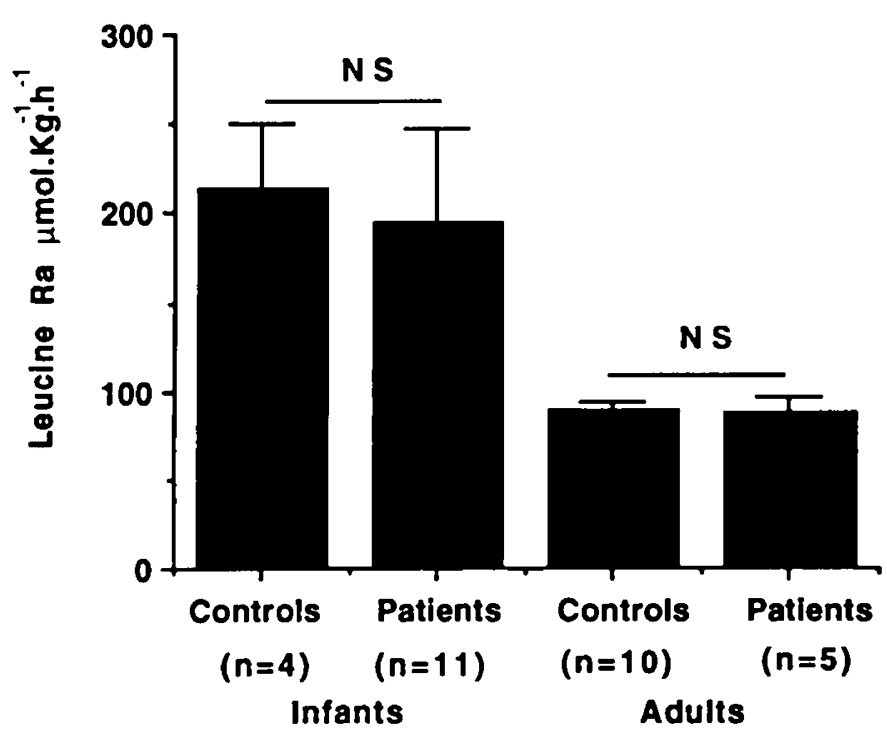

Figure 1. Leucine $\mathrm{Ra}$ in enterectomized children (current study) and adults (8) compared with their respective controls. 


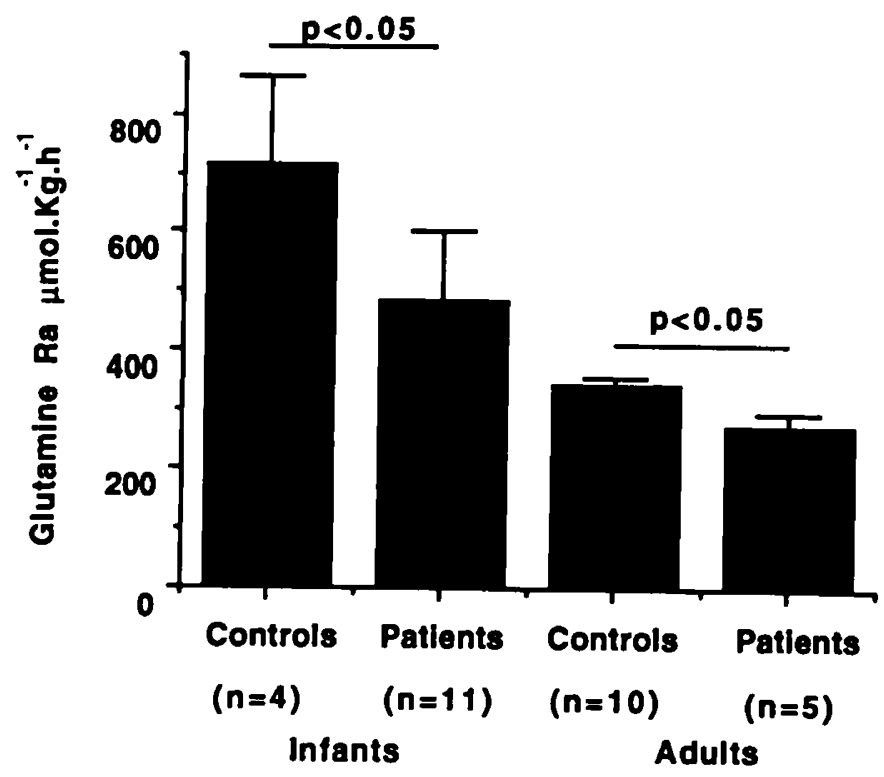

Figure 2. Glutamine Ra in enterectomized children (current study) and adults (8) compared with their respective controls.

contribute to the higher disposal rate observed in infants: 1) an enhanced rate of oxidation by developing enterocytes, such as that documented in the isolated small intestine of developing animals (9); 2) a decline in the mass of intestinal tissue relative to total body mass with increasing age (24); and 3) finally, an increased uptake by other growing tissues such as the immune system or the bone marrow, inasmuch as glutamine is known to serve both as a major fuel and as a source of nitrogen for nucleic acid synthesis in rapidly replicating cells (2) and cell replication is more active during infancy.

Finally, although the present findings point to the small intestine as a preferential user of glutamine in human infants, they do not provide any clue as to the role(s) of glutamine in that organ. Previous studies performed in animals indeed suggest that glutamine may not only supply energy but may promote electrolyte absorption (25) and support intestinal trophicity and immune function (26-28) as well. Taken together, the accumulated evidence suggests that the effects of glutamine on the small intestine warrant further investigation in the human infant.

\section{REFERENCES}

1. Hartzmann F, Plauth M 1989 Intestinal glutamine metabolism. Metabolism 38(suppl 1): 18-24
2. Lacey JM, Wilmore DW 1990 Is glutamine a conditionally essential amino acid? Nutr Rev 48:297-309

3. Windmueller HG, Spaeth A 1978 Identification of ketone bodies and glutamine as the major respiratory fuels in vivo for postabsorptive rat small intestine. J Biol Chem 253:69-76

4. Felig P, Wahren J, Karl I, Cerasi E, Luft R, Kipnis D 1973 Glutamine and glutamate metabolism in normal and diabetic subjects. Diabetes 22:573-576

5. McAnena OJ, Moore FA, Moore EE, Jones TN, Parsons P 1991 Selective uptake of glutamine in the gastrointestinal tract: confirmation in a human study. Br J Surg 78:480—482

6. Darmaun D, Matthews DE, Bier DM 1986 Glutamine and glutamate kinetics in humans. Am J Physiol 251:E117-E126

7. Darmaun D, Manary MJ, Matthews DE 1985 A method for measuring both glutamine and glutamate levels and stable isotopic enrichments. Anal Biochem 147:92-102

8. Darmaun D, Messing M, Just B, Rongier M, Desjeux JF 1991 Glutamine metabolism after small intestinal resection in humans. Metabolism 40:42-44

9. Kimura RE 1987 Glutamine oxidation by developing rat small intestine. Pediatr Res 21:214-217

10. Brook CGD 1971 Determination of body composition of children from skinfold measurements. Arch Dis Child 46:182-184

11. Siri WE 1961 Body composition from fluid spaces and density: analysis of methods. In: Techniques for Measuring Body Composition. National Academy of Sciences, National Research Council, Washington, DC, pp 223-244

12. Abumrad NN, Rabin D, Diamond MP, Lacy WW 1981 Use of a heated superficial hand vein as an alternative site for the measurement of amino acid concentrations and for the study of glucose and alanine kinetics in man. Metabolism 30:936-941

13. Darmaun D, Froguel P, Rongier M, Robert JJ 1989 Amino acid exchange between plasma and erythrocytes in vivo in humans. J Appl Physiol 67:23832388

14. Ravussin E, Bogardus C 1989 Relationship of genetics, age, and physical fitness to daily energy expenditure and fuel utilization. Am J Clin Nutr 49(suppl):968-975

15. Lo CW, Walker WA 1989 Changes in the gastrointestinal tract during enteral and parenteral feeding. Nutr Rev 47:193-198

16. Goulet O, Revillon Y, Jan D, De Potter S, Maurage C, Lortat-Jacob S, Martelli H, Nihoul-Fekete C, Ricour C 1991 Neonatal short bowel syndrome. J Pediatr 119:18-23

17. Motil KJ 1993 Development of the gastrointestinal tract. In: Wyllie R, Hyams JS (eds) Pediatric Gastrointestinal Disease. WB Saunders, Philadelphia, pp 3-16

18. Fong Y, Tracey KJ, Hesse DG, Albert JD, Barie PS, Lowry SF 1990 Influence of enterectomy on peripheral tissue glutamine efflux in critically ill patients. Surgery 107:321-326

19. Felig P 1975 Amino acid metabolism in man. Annu Rev Biochem 44:933-955

20. Bucci A, Toft I, Jenssen T, Bier D, Nurjhan N 1992 Glutamine metabolism and its contribution to glucose and alanine production in man. Diabetes 41(suppl 1):68A(abstr)

21. Smith RJ, Larson S, Stred SE, Durschlag RP 1984 Regulation of glutamine synthetase and glutaminase activities in cultured skeletal muscle cells. J Cel Physiol 120:197-203

22. Denne SC, Kalhan SC 1987 Leucine metabolism in human newborns. Am J Physiol 253:E608-E615

23. Beaufrère B, Putet G, Pachiaudi C, Salle B 1990 Whole body protein turnover measured with ${ }^{13} \mathrm{C}$-leucine and energy expenditure in preterm infants. Pediatr Res $28: 147-152$

24. Widdowson EM 1974 Changes in body proportions and composition during growth. In: Davis SA, Dobbing J (eds) Scientific Foundations of Pediatrics. WB Saunders, Philadelphia, pp 153-173

25. Nath SK, Déchelotte P, Darmaun D, Gotteland M, Rongier M, Desjeux JF

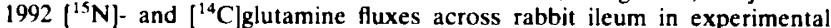
bacterial diarrhea. Am J Physiol 262:G312-G318

26. Burke DJ, Alverdy JC, Aoys E, Moss GC 1989 Glutamine-supplemented total parenteral nutrition improves gut immune function. Arch Surg 124:1396-1399

27. Fox AD, Kripke SA, De Paula J, Berman JM, Settle RG, Rombeau J 1988 Effect of a glutamine supplemented enteral diet on methotrexate induced enterocolitis. J Parenter Enteral Nutr 12:325-331

28. Klimberg VS, Souba WW, Dodson DJ, Salloum RM, Hautamaki RD, Plumley DA, Mendenhall WM, Bova FJ, Khan SR, Hackett RL, Bland KI, Copeland EM 1990 Prophylactic glutamine protects the intestinal mucosa from radiation injury. Cancer 66:62-68 